PYTHAGORAS: Jurnal Pendidikan Matematika

Volume 10 - Nomor 2, Desember 2015, (137-145)

Available online at: http://journal.uny.ac.id/index.php/pythagoras

\title{
Pengembangan Perangkat Pembelajaran Berbasis Pemecahan Masalah Berorientasi pada Kemampuan Penalaran dan Komunikasi Matematika
}

\author{
Furdan Rahmadi \\ SMK Negeri 6 Yogyakarta. Jalan Kenari No.4, Semaki, Umbulharjo, Kota Yogyakarta, Daerah \\ Istimewa Yogyakarta, Indonesia. Email: furdan1234@gmail.com
}

\begin{abstract}
Abstrak
Penilitian ini bertujuan untuk menghasilkan perangkat pembelajaran matematika berbasis pemecahan masalah berorientasi pada kemampuan penalaran dan komonikasi matematika siswa kelas $\mathrm{X}$ di SMK bidang keahlian akomodasi perhotelan. Jenis penelitian ini adalah penelitian pengembangan (Research and Development). Penelitian ini bertujuan utuk mengembangkan perangkat pembelajaran dengan menggunakan model pengembangan 3D (Define, Design, Develop) yang dikembangkan oleh Borg dan Gall. Subjek penelitian ini adalah 65 siswa kelas X SMK Negeri 6 Yogyakarta. Analisis data dilakukan dengan mengkonversi total skor aktual yang diperoleh menjadi data kualitatif skala lima. Penelitian ini menghasilkan perangkat pembelajaran matematika materi barisan dan deret yang, meliputi RPP, LKS, dan THB. Dari hasil validasi ahli, skor penilaian guru, penilaian siswa, observasi pembelajaran dan tes evaluasi menunjukkan bahwa RPP, LKS, dan THB adalah valid, praktis, dan efektif. Secara keseluruhan hasil penelitian menunjukkan bahwa perangkat pembelajaran yang dikembangkan adalah layak untuk digunakan.

Kata Kunci: pengembangan, perangkat pembelajaran,kemampuan penalaran, komunikasi matematika

\section{Developing Problem Based Learning Kits Oriented Toward Reasoning Ability and Math Communication of Students for Sequences and for Series Materials}

Abstract

This study aims to produce problem-based learning kits which are valid, practical, and effective oriented toward mathematical reasoning ability and mathematics communication of Vocational School of Hotel acomodatioan. This study was a research and development study. It developed learning kits using Borg and Gall development model, and the model was modified so that it included only Define, Design, and Develop. This study produced learning kits for the problem-based learning oriented reasoning ability and communication students for the topic of sequence and series. The kits consisted of lesson plan, student work sheet, and achievement test. The results of the validation show that the developed kits are feasible to use and in the good category. The results of tryouts showed that the developed kits are practical and effective to develop mathematics reasoning ability and mathematics communication of the students. The Practicality in tryout was in good category with an average capability of being implemented in learning of $83.33 \%$ and the field tryout us in the good category with an average of improvement of $90.33 \%$. Based on the achievement test, it shows that the achievement of learning outcomes with a minimum completeness is $78.33 \%$.
\end{abstract}

Keywords: development, reasoning ability, communication of mathematics.

How to Cite Item: Rahmadi, F. (2015). Pengembangan perangkat pembelajaran berbasis pemecahan masalah berorientasi pada kemampuan penalaran dan komunikasi matematika. PYTHAGORAS: Jurnal Pendidikan Matematika, 10(2), 137-145. Retrieved fromhttp://journal.uny.ac.id/index.php/pythagoras/article/view/9133 


\section{Pythagoras, 10 (2), Desember 2015 - 138}

Furdan Rahmadi

\section{PENDAHULUAN}

Pada era globalisasi seperti sekarang ini bangsa yang tidak mampu menghadapi kemajuan di berbagai bidang akan menjadi bangsa yang tertinggal. Era informasi global memungkinkan seseorang untuk mendapatkan informasi secara cepat dan mudah dari barbagai sumber, seseorang juga memiliki kemampuan untuk mengolah, mengelola dan menindaklanjuti informasi yang didapat untuk dimanfaatkan dalam kehidupan yang pernuh tantangan agar tidak tenggelam dalam keterpurukan di berbagai persoalan hidup.

Hal ini mennyebabkan pendidikan menjadi prioritas dalam pembangunan manusia Indonesia yang seutuhnya. Pendidikan adalah proses pembentukan dan pengembangan daya nalar, keterampilan, dan moralitas kehidupan terhadap potensi yang dimiliki oleh setiap manusia. Suatu pendidikan dikatakan bermutu apabila proses pendidikan berlangsung secara efektif sehingga peserta didik memperoleh pengalaman yang bermakna bagi dirinya, dan produk dari pendidikan adalah individu-individu yang unggul dan bermanfaat bagi masyarakat dan pembangunan bangsa.

Undang Undang Republik Indonesia Nomor 20 tahun 2003 tentang Sistem Pendidikan Nasional menyatakan bahwa pendidikan adalah usaha sadar dan terencana untuk mewujudkan suasana belajar dan proses pembelajaran agar peserta didik secara aktif mengembangkan potensi dirinya untuk memiliki kekuatan spiritual keagamaan, pengendalian diri, kepribadian, kecerdasan, akhlak mulia serta keterampilan yang diperlukan bagi dirinya, masyarakat, bangsa dan negara.

Peraturan Pemerintah Nomor 65 tahun 2013 tentang Standar Proses menyebutkan bahwa setiap pendidik pada satuan pendidikan berkewajiban menyusun Rencana Pelaksanaan Pembelajaran (RPP) secara lengkap dan sistematis agar pembelajaran berlangsung secara interaktik, inspiratif, menyenangkan, menantang, memotivasi peserta didik untuk berpartisipasi aktif dan memberikan ruang yang cukup bagi prakarsa, kreatifitas dan kemandirian sesuai bakat, minat dan perkembangan fisik serta psikologis peserta didik. Dengan demikian, setiap satuan pendidikan perlu melakukan perencanaan dalam pembelajaran, pelaksanaan proses pembelajaran serta penilaian selama proses pembelajaran dengan menggunakan strategi untuk meningkatkan efisiensi dan efektifitas agar tercapai kompetensi lulusan yang diharapkan.

Pendidikan memerlukan kemampuan untuk mengimplementasikan apa yang menjadi harapan, ide-ide tertentu dalam kehidupan termasuk dalam menggunkan bahasa yang baik dan dapat diterima tanpa mengurangi maksud dan tujuan yang dikehendaki, juga ketika menerima pendapat serta gagasan dari orang lain. Ide atau gagasan yang dikemukakan dalam menyelesaikan masalah memerlukan komentar atau tangggapan dari siapa saja yang diharapkan dapat mempercepat dalam proses pengambilan keputusan, dengan kata lain proses pendidikan perlu komunikasi untuk menjawab permsalahan dalam kehidupan.

Kegiatan komunikasi agar bisa mendukung dalam menyelesaikan persoalan hidup membutuhkan ketrampilan penalaran untuk menghubungkan fakta-fakta dan pendapatpendapat yang berkaitan dengan persoalan yang dihadapi, hal ini senada dengan pembelajaran matematika yang di harapkan menjadi ruh pembelajaran matematika. Permendikbud No. 64 tahun 2013 tentang standar isi secara detail menyatakan bahwa pembelajaran matematika bertujuan agar peserta didik memiliki kemampuan sebagai berikut: (1) memahami konsep (2) menggunakan penalaran (3) memecahkan masalah (4) mengkomunkasikan gagasan (5) memilki sikap menghargai kegunaan matematik.

Peran guru sebagai fasilitator harus mampu mengemas kegiatan pembelajaran menjadi efektif, efisien, ilmiah dan menyenangkan. Kegiatan pembelajaran diharapkan dapat membekali siswa agar memiliki kesiapan untuk menghadapi tantangan kehidupan di masyarakat dalam memecahkan masalah yang cepat dan tepat.

Peranan pembelajaran matematika dalam meningkatkan kemampuan komunikasi dan penalaran menjadi sangat sentral, dalam proses pembelajaran matematika masih banyak ditemukan kegagalan karena guru tidak memberikan pengalaman penalaran sehingga siswa tidak mampu mengemukakan pendapat dan memberikan penjelasan (Jones:2009).

Fauzan (2009, p.1) menyatakan bahwa kegagalan pembelajaran matematika sering disebabkan kurangnya kemampuan penalaran matematika siswa disamping kurangnya pemahaman konsep dasar matematika.

Sementara itu Julie-Ann (2004, p,7) menyatakan bahwa inti dari pembelajaran matematika adalah penyelesaian masalah (problem 
solving). Nitko (2011, p,37) pemecahan masalah merupakan bagian dari kebutuhan yang sangat penting karena dalam proses pembelajaran sehingga dimungkinkan siswa memperoleh pengalaman dalam menggunakan pengetahuan serta keterampilan yang dimiliki untuk diterapkan pada pemecahan masalah yang dihadapi keseharian dan masalah yang tidak rutin.

Selanjutnya, Arends (2000, p,328) menyatakan bahwa " real-world problems capture students' interest and are motivating" Hal tersebut dapat dimaknai bahwa permasalahan keseharian dapat membuat siswa tertarik dan memotivasi siswa untuk belajar.

Sedangkan, Djamarah (2006, p.91) pendekatan problem solving (pemecahan masalah) bukan hanya sekedar mengajar, tetapi juga merupakan suatu pendekatan melalui cara berpikir, sebab dalam problem solving siswa dapat menggunakan berbagai alternatif penyelesaian dengan metode-metode lainnya yang dimulai dengan mencari pokok permaslahan (oeientasi masalah), mengumpulkan data sampai kepada menarik kesimpulan dan menyampaikan kesimpulan kepada orang lain (mengkomonikasikan) apa yang disimpulkan.

Permasalahan mengenai kemampuan pemecahan masalah dan pembelajaran sering kita temui dalam beberapa kasus penelitian diantaranya penelitian oleh Subanindra (2012). Hasil penelitian ini menyatakan bahwa pendekatan berbasis masalah dapat lebih meningkatkan kemampuan penalaran dan komunikasi matematika siswa.

Kurikulum 2013 mengamanatkan siswa untuk mampu dan memiliki bekal sikap, pengetahuan dan ketrampilan yang cukup dalam penyelesaian masalah dalam kehidupan. Dengan demikian, guru harus mampu merancang perangkat pembelajaran yang mampu memberikan pengalaman belajar kepada siswa.

Dalam menyiapkan kemampuan guru untuk merancang dan melaksanakan pembelajaran berbasis pemecahan masalah dan meningkatkan kemampuan penalaran dan komunikasi matematika perlu disiapkan silabus sebagai acuan, perlu penjabaran operasional dalam mengembangkan materi dan langkah-langkah pembelajaran, sehingga diperlukan rambu rambu yang bisa menfasilitasi guru dalam menyikapi, menyamakan presepsi dan pemahaman dalam membuat perangkat pembelajaran.

Penguasaan pada materi barisan dan deret secara nasional untuk siswa SMK masih menunjukkan dibawah kreteria ketuntasan nasioanl
(75). Hal ini ditunjukan oleh laporan hasil ujian nasional yang dikeluarkan oleh Badan Nasional Standar Pendidikan untuk tahun 2012-2013. Dari 9583 sekolah negeri dan swasta, 1.118.512 siswa SMK di Indonesia rata-rata penguasaan materi barisan dan deret 39,89\%.

Upaya untuk meningkatkan hasil belajar siswa dalam pembelajaran matematika, guru perlu memperhatikan beberapa hal yang menjadi sebab rendahnya hasil pembelajaran matematika siswa yang meliputi pemahaman konsep, pemecahan masalah dan kemampuan untuk mepresentasikannya, kemampuan yang dimaksud salah satunya kemampuan yang diperlukan untuk menyelesaikan masalah dalam pembelajaran matematika yaitu kemampuan penalaran dan komunikasi matematika siswa.

Berdasarkan pemaparan tersebut maka peneliti berkesimpulan bahwa penting sekali untuk mengembangkan perangkat pembelajaran matematika berbasis pemecahan masalah dan berorientasi pada kemampuan penalaran dan komunikasi matematika siswa pada materi barisan dan deret dikelas X SMK bidang keahlian Akomodasi Perhotelan.

Perangkat pembelajaran yang dikembangkan dalam penelitian ini terdiri atas Rencana Pelksanaan Pembelajaran (RPP), Lembar Kegiatan Siswa (LKS) dan Tes hasil Belajar (THB).

Penelitian pengembangan ini bertujuan untuk mengembangkan perangkat pembelajaran berbasis masalah dan berorientasi pada kemampuan penalaaran dan komunikasi matematika siswa kelas X SMK Negeri 6 Yogyakarta bidang keahlian Akomodasi Perhotelan dengan menggunakan model pengembangan 3D (Define, Design, Develop) yang dikembangkan oleh Borg dan Gall.

\section{METODE}

Jenis penelitian ini adalah penelitian pengembangan. Penelitian ini difokuskan pada pengembangan produk berupa perangkat pembelajaran matematika berbasis masalah berorientasi pada kemampuan penalaran dan komunikasi matematika Produk yang dikembangkan yaitu Rencana Pelaksanaan Pembelajaran (RPP), Lembar Kegiatan Siswa (LKS), Tes Hasil Belajar (THB).

Subjek penelitian ini adalah60 siswa kelas X SMK Negeri 6 Yogyakarta bidang keahlian Akomodasi Perhotelan terutama kelas X.AP1 X.A23. Waktu penelitian adalah semester 2 tahun pelajaran 2014-2015. 


\section{Pythagoras, 10 (2), Desember 2015 - 140}

Furdan Rahmadi

Model pengembangan penelitian ini dilakukan dan diadaptasi dari model pengembangan Borg dan Gall dengan dilakukan beberapa modifikasi sesuai dengan kondisi pada penelitian ini. Dari sepuluh tahap pengembangan model Borg dan Gall dimodivikasi menjadi tiga tahap penelitian, yaitu meliputi define, design dan development. Tahap define tahap ini bertujuan untuk menentukan dan mendefinisikan syarat-syarat pembelajaran (Research and information collecting), dan langkah kedua Tahap design, pada tahap ini dilakukan perancangan perangkat pembelajaran yang meliputi RPP, LKS, dan $T H B$. Tahap ketiga merupakan tahap pengembangan development pada tahapan ini meliputi langkah uji kevalidan, kepraktisan, dan keefektifan perangkat pembelajaran.

Prosedur pengembangan penelitian melalui 3 tahap yaitu; define, design, dan development. Pada tahap define peneliti melakukan pengumpulan informasi-informasi berkaitan dengan produk yang akan dikembangkan meliputi beberapa analisis yaitu: (1) Analisis Pembelajaran; (2). Analisis Siswa; (3) Analisis Materi; (4) Analisis Tugas; dan (5) Spesifikasi tujuan pembelajaran. Pengumpulan informasi dilakukan dengan studi pustaka dan studi lapangan.

Pada tahap perancangan (design) dilakukan beberapa langkah pengembangan produk yaitu untuk mendapatkan perangkat pembelajaran berupa Rencana Pelaksanaan Pembelajaran (RPP), Lembar Kegiatan Siswa (LKS), Tes Hasil Belajar (THB).

Rancangan perangkat pembelajaran yang berupa RPP, LKS, dan THB pada penelitian ini menggunakan pendekatan pembelajaran berbasis masalah (problem based learning) yang diadopsi dari problem solving model Polya yang terdiri atas empat langkah yaitu: (1) Understanding the problem (orientasi masalah); (2) Devising a plan (merencanakan penyelesaian); (3) Carrying out the plan (melaksanakan rencana); (4) Looking back (melihat kembali hasil pekerjaan). Dari tahapan ke dua didapatkan produk yang berupa draf ke-1 yang selanjutnya dilakukan validasi, uji coba, dan revisi sehingga didapatkan produk yang valid, praktis, dan efektif.

Tahap pengembangan development pada tahapan ini bertujuan untuk membuat produk yang dapat diterima oleh siswa dan mudah disampaikan oleh guru, maka menurut Cobb, et al., (2011, p.76) mengatakan tujuan dari sebuah desain penelitian tidak hanya untuk membangun sebuah kontruksi yang jelas, tetapi juga mencakup pengembangan, pengujian dan untuk memperbaiki pruduk yang dihasilkan serta diharapkan dapat meningkatkan aktivitas pembelajaran.

Kualitas pruduk hasil penelitian dan pengembangan berperan untuk meningkatkan efektifitas pembelajaran, menurut Nieveen (1999, p.26) hasil produk penelitian memainkan peranan yang penting dalam pendidikan. Untuk memenuhi fungsi diatas, produk harus mempunyai kriteria yang baik. Maka untuk memenuhi kriteria pembelajaran dan kualitas produk yang baik pada penelitian ini digunakan kriteria kualitas produk menurut Nieveen yang meliputi kriteria kevalidan, kriteria kepraksian, dan kriteria keefektifan. Langkah-langkah yang dilakukan untuk memenuhi criteria tersebut meliputi:

Validasi yang terdiri atas validasi ahli dan uji validasi praktisi. Produk yang dihasilkan dari tahap ke-2 dilakukan validasi oleh dua ahli materi dan seorang validasi instrumen sehingga dapat diketahui apakah produk yang dihasilkan telah sesuai dan layak digunakan. Selanjutnya dilakukan uji validasi praktisi dari penilaian tiga orang guru di SMKNegeri 6 Yogyakarta.

Setelah dilakukan validasi oleh para ahli, maupun oleh praktisi selanjutnya akan dilakukan analisis terhadap hasil validasi dan dilakukan revisi atas dasar saran dan masukan dari validator, sehingga didapatkan produk yang layak dan dapat digunakan. Produk revisi hasil validasi ahli ini dinamakan dengan produk draf 2 .

Uji coba terbatas, produk draf 2 sebagai hasil dari validasi i kemudian diujicobakan pada kelompok terbatas yang dinamakan uji coba terbatas. Uji kelompok terbatas dilakukan untuk menguji kualitas produk pengembangan pada skala kecil. Uji coba ini meliputi uji keterbacaan dan pelaksanaan pembelajaran yang menggunakan produk draf 2. Setelah dilakukan uji coba terbatas, selanjutnya akan dilakukan analisis dari hasil uji coba tersebut. Apabila hasil dari uji coba terbatas membutuhkan perbaikan, maka produk dilakukan revisi. Produk revisi hasil uji coba terbatas ini dinamakan dengan produk draf 3 , dan selanjutnya dilakukan uji coba lapangan.

Uji coba lapangan, uji coba lapangan ini bertujuan untuk mengetahui kepraktisan dan keefektifan produk. Uji coba lapangan dilakukan untuk menguji kualitas produk pengembangan pada skala yang lebih besar. Kepraktisan produk dapat diketahui dari data penilaian guru terhadap perangkat pembelajaran yang dikembangkan, angket respon siswa untuk mengetahui penilaian siswa terhadap pembelajaran yang menggunakan perangkat pembelajaran hasil pengembang- 


\section{Pythagoras, 10 (2), Desember 2015 - 141}

Furdan Rahmadi

an, dan lembar observasi keterlaksanaan pembelajaran di kelas. Sedangkan untuk mengetahui keefektifan produk dilakukan analisis ketuntasan pembelajaran yang dapat diketahui dari hasil tes hasil belajar kemampuan penalaran dan komunikasi matematika (THB).

Data hasil uji lapangan yang telah didapatkan selanjutnya akan dilakukan analisis data sehingga diketahui kevalidan, kepraktisan dan keefektifan produk. Apabila hasil analisis data telah memenuhi kriteria kevalidan, kepraktisan dan keefektifan, maka produk tersebut adalah produk akhir. Jika hasil analisis menunjukkan belum memenuhi kriteria kepraktisan dan keefektifan,maka dilakukan revisi produk kembali.

Jenis data dalam penelitian ini meliputi data kuantitatif dan data kualitatif. Data-data ini bertujuan untuk memberi gambaran mengenai kualitas produk yang dikembangkan. Data kuantitatif diperoleh dari validasi ahli, lembar penilaian guru, lembar observasi, angket respon guru, angket respon siswa, dan tes hasil belajar. Skor data kuantitatif dikonversi menjadi data kualitatif untuk menentukan kriteria dari suatu produk.

Instrumen yang digunakan pada penelitian ini yaitu untuk mengumpulkan data tentang kategori kevalidan, kepraktisan, dan keefektifan produk. Instrumen yang digunakan dalam penelitian ini meliputi: Instrumen Validasi Format untuk mengetahui keavildan instrumen yang akan digunakan dalam penelitian, Instrumen Penilaian Kevalidan, yang terdiri atas lembar validasi RPP, lembar validasi LKS, lembar validasi tes hasili belajar, Penilaian Kepraktisan terdiri atas lembar penilaian guru, lembar respon siswa, lembar observasi keterlaksanaan pembelajaran. Instumen Penilaian Keefektifan terdiri atas tes hasil belajar yang merupakan tes kemampuan penalaran dan komunikasi matematika.

\section{Teknik Analisis Data}

Teknik analisis data pada penelitian ini adalah untuk menentukan apakah produk yang dikembangkan memenuhi syarat kevalidan, kepraktisan, dan keefektifan. Jika syarat-syarat terpenuhi maka didapatkan produk yang layak digunakan. Data yang didapatkan dalam penelitian ini yaitu data yang bersumber dari lembar validasi, lembar penilaian guru, lembar observasi, angket respon siswa, THB. Teknik analisis dari data yang didapatkan adalah sebagai berikut:
Secara umum data yang diperolah berupa skor (data kuantitatif) selanjutnya diubah menjadi data kualitatif dengan mengelompokkan data yang diperoleh berdasarkan kualifikasi produk yang dinilai. Selanjutnya dilakukan perhitungan rata-rata atas data yang diperoleh dan telah dikelompokkan. Untuk menghitung ratarata skor menggunakan acuan sebagai berikut.

$$
\bar{x}=\frac{\sum x}{n}
$$

Keterangan

$\bar{x}=$ skor rata-rata,

$\sum x=$ total skor jawaban,

$\mathrm{N}$ = banyak evaluator

Skor rata-rata yang didapatkan kemudian diubah kedalam kriteria kualitatif dengan ketentuan seperti pada Tabel 1. yang diadopsi dari Direktorat Pembinaan SMA (2010, pp.59$60)$.

Tabel 1. Kriteria Penilaian Skala Likert

\begin{tabular}{|c|c|}
\hline Interval & Kriteria \\
\hline$M_{i}+1,8 S D i<\bar{M}$ & SB \\
\hline$M_{i}+0,6 S D i<\bar{M} \leq M_{i}+1,8 S D i$ & $\mathbf{B}$ \\
\hline$M_{i}-0,6 S D i<\bar{M} \leq M_{i}+0,6 S D i$ & $\mathbf{C}$ \\
\hline $\begin{aligned} M_{i}-\frac{1,8 S D i}{M} & <\bar{M} \leq M_{i}-0,6 S D i \\
& \leq M_{i}-1,8 S D i\end{aligned}$ & $\begin{array}{c}\mathbf{K} \\
\mathbf{S K}\end{array}$ \\
\hline
\end{tabular}

Keterangan:

$\bar{M}=$ Rata-rata akhir

$M_{i}=$ Rata-rata ideal

$=1 / 2($ skor maksimun ideal + skor minimum ideal $)$

$S D i=$ Standar deviasi ideal

$=\frac{1}{6}($ skor maksimun ideal - skor minimum ideal $)$

Skor maksimal ideal $=\Sigma$ butir kriteria $\times$ skor tertinggi

Skor minimum ideal $=\Sigma$ butir kriteria $\times$ skor terendah.

Data-data hasil penelitian ini selanjutnya dianalisis untuk mendapatkan kriteria kualitas dari perangkat pembelajaran yang dikembangkan. Analisis data ini dibagi atas 3 kategori yaitu analisis kevalidan perangkat pembelajaran, analisis kepraktisan perangkat pembelajaran dan analisis keefektifan perangkat pembelajaran.

Perangkat pembelajaran dikatakan valid jika memenuhi kriteria B, Kriteria kualitatif yang digunakan pada lembar validasi ahli adalah sangat valid (A), valid (B), cukup valid (C), kurang valid (D) dan sangat kurang valid (E). Pada lembar penilaian guru digunakan kriteria kepraktisan sangat praktis (A), praktis (B), cukup praktis (C), kurang praktis (D) dan sangat kurang praktis (E). Sedangkan untuk lembar penilaian siswa digunakan kriteria sangat 
menyenangkan (A), menyenangkan (B), cukup menyenangkan (C), kurang menyenangkan (D), dan sangat kurang menyenangkan (E). Perangkat pembelajaran dikatakan praktis jika hasil penilaian guru minimal kategori praktis (B), dan hasil penilaian siswa minimal memenuhi kriteria menyenangkan (B).

Pada kriteria keefektifan penelitian ini ditinjau dari tes hasil belajar (tes kemampuan penalaran dan komunikasi matematika). Perangkat pembelajaran materi barisan dan deret dikatakan efektif apabila presentasi hasil tes belajar siswa pada materi barisan dan deret mencapai kriteria ketuntasan belajar secara klasikal yaitu minimal $75 \%$ sesuai dengan kriteria yang berlaku disekolah yaitu KKM untuk pelajaran matematika wajib yaitu 75 .

Analisis hasil tes hasil belajar diperoleh dengan cara menghitung hasil tes untuk menentukan tingkat ketuntasan belajar siswa dengan menggunakan perangkat yang dikembangkan. Data hasil siswa mengerjakan soal-soal THB akan dianalisis untuk melihat tingkat keefektifan perangkat pembelajaran yang digunakan dalam pembelajaran dengan menghitung presentase ketuntasan siswa. Siswa dikatakan tuntas ketika memperoleh skor yang sudah memenuhi KKM yang berlaku di sekolah yaitu 75 .

\section{HASIL DAN PEMBAHASAN}

Setelah dilakukan perancangan perangkat pembelajaran maka didapatkan draf 1 , dan untuk mendapatkan masukan, saran serta perbaikan maka dilakukan validasi oleh ahli, dan dilakukan juga penilaian terhadap draf 1 . Validasi dilakukan dengan cara memberikan naskah produk draf 1 berupa RPP, LKS, THB, serta lembar validasi kepada validator ahli. Data hasil validasi untuk masing-masing komponen produk perangkat pembelajaran dianalisis dengan menghitung rata-rata skor nyata yang diperoleh tiap komponen. Rata-rata skor nyata yang diperoleh untuk RPP, LKS, dan THB dapat dilihat pada Gambar 1.

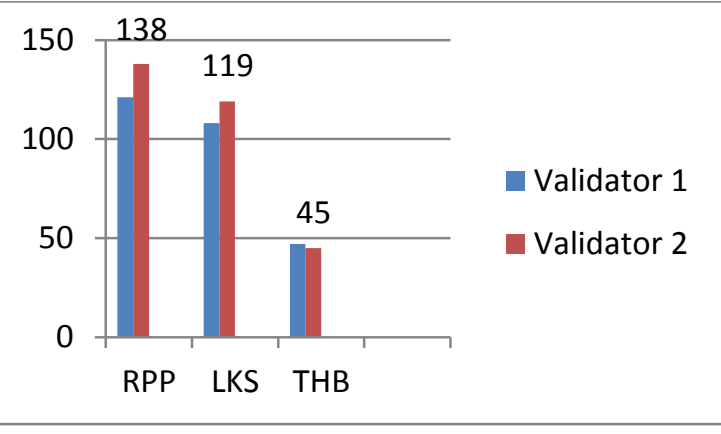

Gambar 1. Skor Validasi Perangkat Pembelajaran

Berdasarkan data dari validasi ahli, maka dilakukan analisis untuk mengetahui kevalidan/ kelayakan produk yang dikembangkan. Kelayakan produk ini berdasarkan data yang berupa rata-rata skor hasil penilaian dari dua validator. Data dari validator yang berupa data kuantitatif dikonversi kedalam data kualitatif. RPP secara keseluruhan dikatakan valid atau layak digunakan apabila skor rata-rata RPP memenuhi kategori minimal B yaitu $\bar{x} \geq 119$. LKS secara keseluruhan dikatakan valid atau layak digunakan apabila skor rata-rata LKS memenuhi kategori minimal $\mathrm{B}$ atau $\bar{x} \geq 102$. skor rata-rata THB memenuhi kategori minimal $\mathrm{B}$ atau $\bar{x} \geq 33,6$

Adapun skor nyata yang diperoleh dan rata-rata skor, serta kategori dari masing-masing produk hasil validasi ahli yang diperoleh disajikan pada Tabel 2.

Tabel.2. Analisis Kevalidan Perangkat Pembelajaran

\begin{tabular}{cccc}
\hline Produk & Skor nyata & rata-rata & Ketegori \\
\hline RPP & 259 & 129,5 & B \\
LKS & 227 & 113,5 & B \\
THB & 92 & 46 & B \\
\hline
\end{tabular}

Perangkat pembelajaran (RPP, LKS, dan THB) draf 3, sebelum diuji cobakan lapangan dimintakan penilaian terhadap 3 guru. Data hasil penilaian perangkat pembelajaran oleh guru yang berupa data kuantitatif dikonversi menjadi data kualitatif untuk menentukan kategori dari kepraktisan perangkat pembelajaran. Perangkat pembelajaran dikatakan praktis jika skor ratarata perangkat pembelajaran memenuhi kategori minimal praktis, yaitu $\bar{x} \geq 102$. Hasil analisis penilaian perangkat pembelajaran oleh guru dalam gambar 2 berikut: 


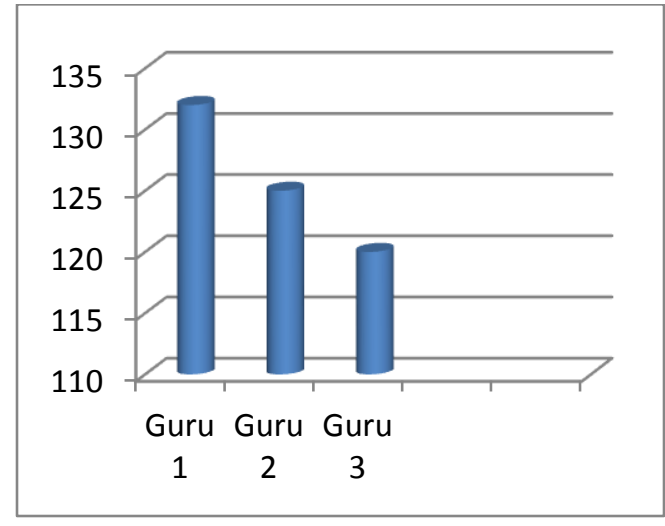

Gambar 2. Skor Penilaian Guru terhadap Perangkat Pembelajaran

Berdasarkan analisis dari data pada Gambar 2. dapat disimpulkan bahwa kepraktisan perangkat pembelajaran yang dikembangkan mendapatkan skor rata-rata 121,33. rata-rata ini termasuk dalam kategori praktis atau B. Hasil penilaian guru terhadap perangkat pembelajaran didapat penilaian masing masing perangkat pembelajaran yang disajikan dalam Gambar 3 .

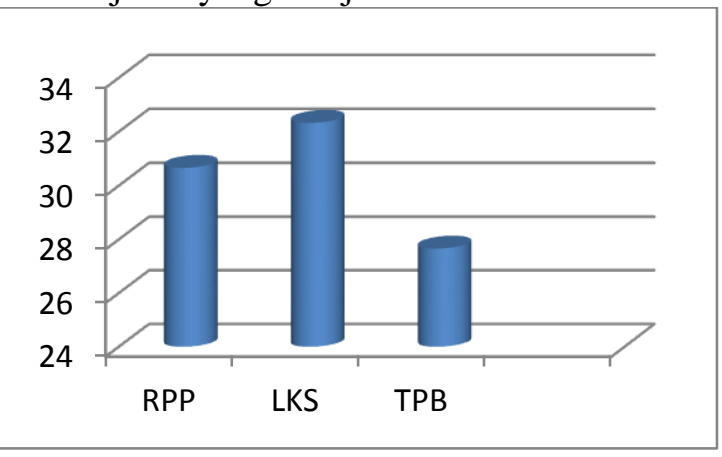

Gambar 3. Rata-rata Hasil Penilaian Guru Setiap Perangkat Pembelajaran.

Berdasarkan hasil analisis penilaian guru terhadap masing-masing perangkat pembelajaran sepert pada Gambar 3, menunjukkan bahwa masing masing perangkat pembelajaran mencapai kategori praktis atau B untuk RPP, LKS, dan THB sehinggaperangkat pembelajaran yang dikembangkan dikategorikan praktis.

Data lembar respon/tanggapan siswa merupakan data kuantitatif yang dikonversi menjadi data kualitatif untuk menentukan kriteria kepraktisan perangkat pembelajaran. Perangkat pembelajaran dikatakan praktis apabila skor rata-rata perangkat pembelajaran berada dalam kategori minimal menyenangkan atau $\mathrm{B}$ yaitu $\bar{x} \geq 54,4$ untuk pembelajaran dan $\bar{x} \geq 46,7$ untuk hasil analisis kepraktisan perangkat pembelajaran berdasarkan respon siswa dapat disajikan dalam Tabel 4 . berikut.
Tabel 4. Analisis Respon Siswa terhadap Perangkat Pembelajaran

\begin{tabular}{ccc}
\hline & Pembelajaran & LKS \\
\hline Skor Total & 5109 & 4495 \\
Rata-rata & 59,41 & 52,27 \\
Kategori & $\mathrm{B}$ & $\mathrm{B}$ \\
\hline
\end{tabular}

Analisis berdasarkan hasil pada Tabel 4 . Didapatkan bahwa skor rata rata terhadap perangkat pembelajaran dikelompokkan menjadi dua yaitu proses kegiatan pembelajaran, setelah seluruh pembelejaran diikuti oleh siswa maka siswa member skor terhadap pembelajaran sebesar 59,4, ini berarti menurut siswa pembelajaran yang menggunakan produk pengembangan dalam penelitian ini berada pada kategori menyenangkan atau (B). Sedangkan dari hasil penilaian LKS yang telah dikerjakan siswa, skor nyata LKS yang diperoleh sebesar 52,27, nilai tersebut berada dalam kategori menyenangkan atau (B). Berdasarkan penilaian siswa tersebut maka perangkat pembelajaran yang dikembangkan dalam penelitian initermasuk kategori praktis berdasar penilaian siswa.

Analisis terhadap data hasil observasi keterlaksanaan pembelajara diperoleh dari hasil observasi keterlaksanaan pembelajaran pada setiap pertemuan. Observasi keterlaksanaan pembelajaran ini meliputi observasi kegiatan guru dan observasi kegiatan siswa. Data observasi kegiatan guru dan siswa dalam 6 pertemuan yang telah dilakukan dapat dilihat Gambar 4 ..

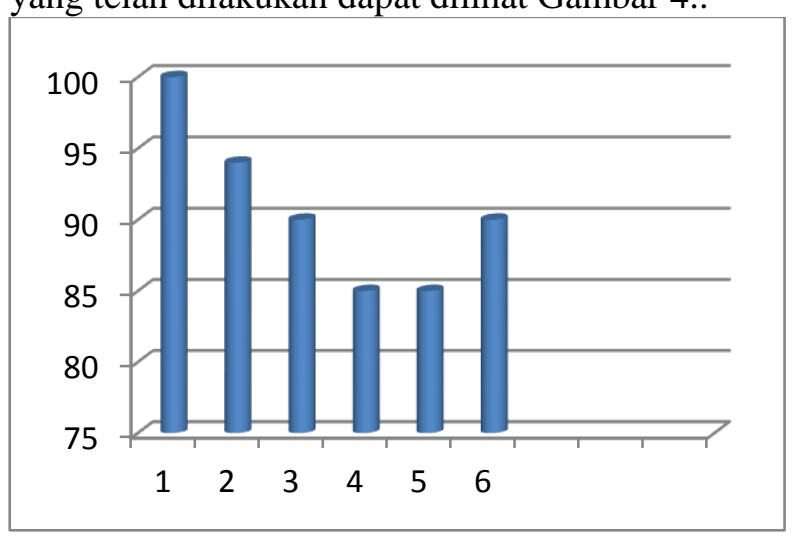

Gambar 4. Diagram Batang Data Observasi Kegiatan Siswa dalam Pembelajaran

Berdasarkan Gambar 4 rata-rata keterlaksanaan 90,33\%. Prosentase keterlaksanaan pembelajaran dari pertemuan ke 1 sampai dengan pertemuan ke 6, semua diatas atau sama dengan $80 \%$. Hal ini berarti bahwa produk yang dikembangkan praktis digunakan dalam pembelajaran. Apabila dilihat dari aspek yang dinilai maka 


\section{Pythagoras, 10 (2), Desember 2015 - 144}

Furdan Rahmadi

analisis hasil observasi kegiatan siswa dapat dilihat pada Gambar 5.

Keefektifan perangkat pembelajaran yang dikembangkan atau produk yang dihasilkan pada penelitian ini dianalisis berdasarkan pada data tes hasil belajar siswa setelah mengikuti seluruh proses pembelajaran. Tes hasil belajar siswa merupakan tes kemampuan penalaran dan komunikasi matematika siswa. Keefektifan perangkat pembelajaran yang dikembangkan diukur dengan memperhatikan tes hasil belajar siswa. Pencapaian ketuntasan belajar siswa secara individual dianggap efektif jika presentase ketuntasan secara yaitu mencapai nilai 75 dan ketuntasan secara klasikal sebanyak $75 \%$ dari jumlah siswa dalam satu kelas..

Data hasil tes prestasi belajar siswa pada penelitian ini menggunakan dua kelas bidang keahlian Akomodasi Perhotelan yaitu kelas X AP 1 dan X AP 2 setelah dilakukan tes maka hasil tes kemampuaan penalaran dan komunikasi matematika pada kedua kelas tersebut dapat disajikanseperti pada Gambar 7.

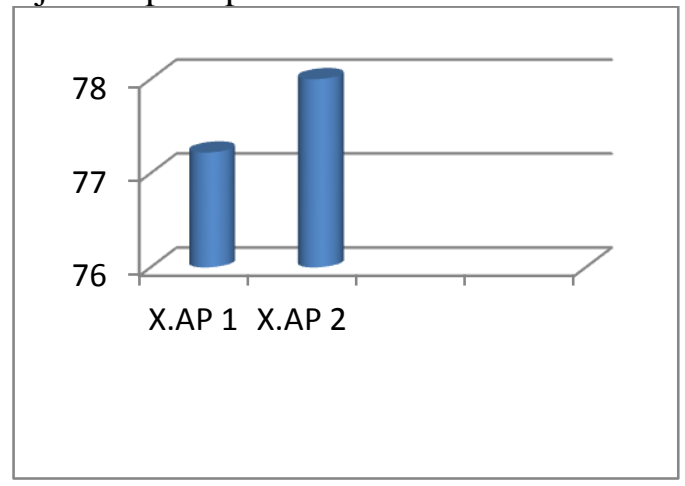

Gambar 7. Rata-rata Hasil Tes Prestasi Belajar

Sedangkan presentase ketuntasannya kelas X.AP 1 mencapai 76,66 \%, kelas X.AP 2 sebesar $80 \%$.Hasil analisis data tersebut menunjukkan bahwa presentase siswa yang mencapai KKM lebih dari 75\%. Sehingga dapat disimpulkan bahwa perangkat pembelajaran yang dikembangkan telah mencapai kriteria efektif.

\section{Simpulan dan Saran}

Semua produk hasil pengembangan perangkat pembelajaran matematika berbasis pemecahan masalah dan berorientasi kemampuan penalaran dan komunikasi matemaatika siswa SMK kelas X bidang akomodasi perhotelan meliputi Rencana Pelaksanaan Pembelajaran (RPP), Lembar Kegiatan Siswa (LKS), Tes hasil Belajar (THB), setelah melalui tahap validasi maka disimpulkan bahwa produk hasil pengembangan tersebut valid.
Setelah melalui tahap uji coba lapangan dan analisis uji coba maka disimpulkan bahwa produk tersebut praktis ditinjau dari penilaian guru dan angket respon siswa, demikian juga ditinjau dari keterlaksanaan pembelajaran. Sedangkan jika ditinjau dari ketuntasan hasil belajar siswa dapat disimpulkan bahwa produk hasil pengembangan tersebut efektif.

Berdasarkan kesimpulan yang dikemukakan, maka beberapa saran yang perlu dipertimbangkan untuk peningkatan kualitas pembelajaran matematika sekolah sebagai berikut:

Bagi guru SMK, karena proses pembelajaran berbasis masalah berorientasi pada kemampuan penalaran dan komunikasi matematika ini belum bisa dikembangkan untuk setiap topik atau materi maka disarankan untuk dapat mengidentifikasi materi-materi yang dapat dikembangkan perencanaan pembelajaran dan semua komponen perangkatnya.

Produk/Perangkat pembelajaran yang telah dikembangkan ini dapat dijadikan sebagai bahan pembelajaran matematika yang berbasis pemecahan masalah untuk meningkatkan kemampuan penalaran dan komunikasi matematika siswa SMK dengan memperhatikan bidang keahlian anak.

Pembelajaran yang dikembangkan hanya terbatas pada bidang keahlian Akomodasi Perhotelan untuk itu disarankan kepada peneliti lain untuk mengembangkannya pada bidang keahlian yang lain atau dengan metode pembelajaran yang berbeda.

\section{DAFTAR PUSTAKA}

Arends, R.I (1997) Clasroom intructions and management. New York: McGraw -Hill CompanyInc.

Barbara, J. (2005). Mathematics teacher education, London: British Library

Borg, W.R., \& Gall, M.D. (1983). Educational reseach an introduction. New York : Longman.

Cobb, P., Gravemeijer, K., \& Yackel, E. (2011). Symbolizing and instructional designdeveloping instructional sequences to support students mathematical learning. Dalam Sfard. A.,

Cowan, P. (2006). Teaching mathematics: A handbook for primary and secondary school teachers. New York: Routledge.

Depdiknas. (2008a). Bahan bimbingan teknis penyusunan KTSP dan silabus sekolah 


\section{Pythagoras, 10 (2), Desember 2015 - 145}

Furdan Rahmadi

menengah kejuruan. Jakarta: Direktorat Pembinaan Sekolah Menengah Kejuruan.

Djamarah, S.B., \& Zain, A. (2013). Strategi belajar mengajar. Jakarta: Rineka Cipta.

Ebel, R. L., \& Frisbie, D. A. (1986). Essentials of educational measurement (4 $4^{\text {th }}$ ed.). Englewood Cliffs, NJ: Prentice-Hall, Inc.

Fauzan, A., Dick Slettenhaar, \& Tjeerd Plomp. (2009), Teaching mathematics in Indonesian primary schools using realistic mathematics education (RME)-approach. Proceedings of the 29th Conference of the International Group for the Psychology of Mathematics Education vol. 2.

Herman, T. (2007). Pengembangan perangkat pembelajaran matematika kemampuan penalaran matematika siswa SMP. Cakrawala Pendidikan, Februari 2007. Th. XXXVI.

Keith, J. ( 2009). Providing a foundation for deductive reasoning students interpretations when using dynamic geometry software and their evolving mathematical explanitions. Centre for Research in
Mathematics Education University of Southampton

Kemp, E.J., Morrison, G.R., \& Ross, S.M. (2004). Designing effective instruction. New York: Merrill.

Kusuma, B.A. (2012). Pengembangan silabus dan rencana pelaksanaan pembelajaran matematika menggunakan pembelajaran kooperatif pada materi pokok trigonometri di SMK kelas X jurusan teknologi komputer jaringan. Tesis magister, tidak diterbitkan, Universitas Negeri Yogyakarta, Yogyakarta.

Nitko, A.J., \& Brookhart, S.M. (2011). Educational assessment of students. Columbus, $\mathrm{OH}$ : Merill.

Peraturan Pemerintah RI Nomor 81 a Tahun 2013 Tentang Implementasi kurikulum pedoman umum pembelajaran. Depdiknas.

Permendiknas No 65 tahun 2013 Tentang Standar proses pendidikan dasar dan menengah.

Uno, B.U. (2008). Model pembelajaran. Jakarta: Bumi Aksara 